\title{
PERANAN IBU DALAM MENGENALKAN PENDIDIKAN SEKS PADA ANAK USIA DINI
}

\author{
Anik Listiyana \\ Jurusan Biologi Fakultas Saintek UIN Maliki Malang
}

Telphone: 081330622252

Email:anik_listiyana@yahoo.com

\begin{abstract}
Abstrak
Maraknya kasus kekerasan seksual pada anak (child abuse) yang dilakukan oleh orang-orang terdekat anak termasuk keluarga menunjukkan pentingnya pemahaman akan pendidikan seks usia dini. Masalah pendidikan seks kurang diperhatikan orang tua pada masa kini sehingga mereka menyerahkan semua pendidikan termasuk pendidikan seks pada sekolah. Padahal yang bertanggungjawab mengajarkan pendidikan seks pada anak usia dini adalah orang tua, sedangkan sekolah hanya sebagai pelengkap dalam memberikan informasi kepada si anak. Hal ini menunjukkan, bahwa peranan orang tua, terutama ibu sangat strategis dalam mengenalkan pendidikan seks sejak dini kepada anak-anak mereka.
\end{abstract}

Kata Kunci: Ibu, pendidikan seks, anak usia dini

\section{A. Pendahuluan}

Masalah seks masih dianggap tabu dibicarakan di depan anak-anak apalagi untuk mengajarkannya kepada anak-anak. Kenyataannya banyak terjadi eksploitasi seks pada anakanak di bawah umur. Seperti yang terjadi di Bali baru-baru ini, yang begitu banyak menyita perhatian, dan menurut Ketua Komnas Perlindungan Anak Seto Mulyadi menjadi kasus yang luar biasa. Hal ini menjadi kasus yang luar biasa karena pelaku memperkosa sebanyak enam orang anak di bawah umur.

Selama ini, pendidikan seks untuk anak usia dini dianggap tabu di kalangan masyarakat. Mereka beranggapan bahwa pendidikan seks belum pantas diberikan pada anak kecil. Padahal dengan pendidikan seks yang diberikan sejak dini sangat berpengaruh dalam kehidupan anak ketika dia memasuki masa remaja. Apalagi anak-anak sekarang kritis, dari segi pertanyaan dan tingkah laku. Itu semua karena pada masa ini anak-anak memiliki rasa keingintahuan yang besar. Pernahkah para pembaca mendengar tentang seorang anak yang bertanya "Adik bayi itu keluar dari mana?" atau "Adik bayi asalnya dari mana?". Untuk itu perlu kiat-kiat khusus dalam memberikan pemahaman tentang seks kepada mereka. Biasanya tak jarang orangtua mengalihkan pembicaraan, kadang mereka membentak dan melarang anak untuk tak menanyakan hal tersebut. Selain itu jawaban yang diberikan malah terkesan ngawur. Padahal jawaban yang demikian bisa memicu anak untuk mengeksplor sendiri, karena mereka merasa penasaran dan berusaha mencari jawaban sendiri, apabila tidak mendapatkannya dari orangtuanya.

Tingginya kasus kekerasan seksual pada anak (child abuse) yang dilakukan oleh orangorang terdekat anak termasuk keluarga menunjukkan pentingnya pemahaman akan pendidikan 
seks usia dini. Masalah pendidikan seks kurang diperhatikan orang tua pada masa kini sehingga mereka menyerahkan semua pendidikan termasuk pendidikan seks pada sekolah.. Padahal yang bertanggungjawab mengajarkan pendidikan seks di usia dini adalah orang tua, sedangkan sekolah hanya sebagai pelengkap dalam memberikan informasi kepada si anak. Peranan orang tua, terutama ibu sangat strategis dalam mengenalkan pendidikan seks sejak dini kepada anakanak mereka.

Menurut Dra. Elly Risman dari Yayasan Kita dan Buah Hati, akses informasi seks pada anak diperoleh baik lewat internet, HP, buku komik dewasa dan anak, Televisi (sinetron, film), $\mathrm{CD}$, Play station dsb, media informasi yang saat ini sangat dekat dengan keseharian anakanak.Semua media informasi tersebut menyerbu anak-anak dan dikemas sedemikian rupa hingga perbuatan seks tersebut dianggap lumrah dan menyenangkan. Dari mulai ciuman, seks bebas (berhubungan seks sebelum nikah, menjual keperawanan,ganti-ganti pasangan dsb), seks bareng, homo/lesbi, hingga incest, semuanya tersedia dalam berbagai media informasi di atas dan jumlahnya membentuk piramida terbalik.

Otak anak-anak yang sekali, dua kali, dan berkali-kali melihat tayangan tersebut akan merekamnya dan membentuknya menjadi suatu pandangan/nilai seksualitas yang dianutnya hingga dia dewasa. Jalan satu-satunya menyikapi fenomena ini adalah kita sebagai orang tua, terutama ibu yang pada kenyataannya lebih dekat dengan anak-anaknya harus berperan membentengi anak-anak kita dengan nilai-nilai seksualitas yang benar yang dilandasi dengan agama.

\section{B. Peran Ibu bagi anak-anaknya}

Anak-anak dalam sebuah keluarga merupakan amanat dan rahmat dari Tuhan, generasi penerus serta pelestari norma yang berlaku dalam keluarga dan masyarakat. Oleh karenanya, keluarga sebagai lingkungan yang pertama dan utama bagi anak seyogyanya mampu menjadi peletak dasar dalam pembentukan karakter yang baik sebagai landasan pengembangan kepribadian anak yang akan membentuk karakter bangsa di kemudian hari. Berbagai keterampilan kehidupan dikembangkan pada anak sejak dini di lingkungan keluarga dalam suasana kasih sayang. Keteladanan dalam suasana hubungan yang harmonis serta komunikasi yang efektif antar anggota keluarga merupakan hal yang fundamental bagi berkembangnya kepribadian anak.

Dorothy Rich, mengemukakan berbagai keterampilan yang harus dimiliki oleh seorang anak. Dia menyebutnya sebagai keterampilan mega (mega skills), yaitu:5 (1) Percaya diri; (2) Motivasi disertai dengan keinginan yang kuat; (3) Daya juang disertai dengan kerja keras; (4) Tanggung jawab; (5) Keuletan; (6) Kepedulian; (7) Team work; (8) Positive thinking; dan (9) Problem solving. Seorang ibu dituntut memiliki pengetahuan dan keterampilan serta kemampuan untuk menjadikan anak-anaknya memiliki Mega Skills. Hal tersebut dapat dicapai dengan 
memberikan latihan dan tugas-tugas yang sesuai dengan kemampuan anak sejalan dengan perkembangan usianya.

Peran ibu bagi anak-anaknya, antara lain: a. Membina keluarga sejahtera sebagai wahana penanaman nilai agama, etik dan moral serta nilai-nilai luhur bangsa, sehingga memiliki integritas kepribadian dan etos kemandirian yang tangguh. b. Memperhatikan kebutuhan anak (perhatian/ atensi, kasih sayang, penerimaan/ acceptance, perawatan/care, dan lain-lain) c. Bersikap bijaksana dengan menciptakan dan memelihara kebahagiaan, kedamaian dankesejahteraan yang berkualitas dalam keluarga serta pemahaman atas potensi dan keterbatasan anak. d. Melaksanakan peran pendamping terhadap anak, baik dalam belajar, bermain dan bergaul, serta menegakkan disiplin dalam rumah, membina kepatuhan dan ketaatan pada aturan keluarga. e. Mencurahkan kasih sayang namun tidak memanjakan, melaksanakan kondisi yang ketat dan tegas namun bukan tidak percaya atau mengekang anggota keluarga. f. Berperan sebagai kawan terhadap anak-anaknya, sehingga dapat membantu mencari jalan keluar dari kesulitan yang dialami anak-anaknya. g. Memotivasi anak dan mendorong untuk meraih prestasi yang setinggi tingginya. Semua itu dilaksanakan dengan ketulusan, kesabaran dan konsisten dengan komitmen semata-mata demi kesuksesan dan kebahagiaan anak.

Usia anak dalam sebuah keluarga sangat bervariasi. Setiap tahap perkembangan individu mempunyai karateristik tersendiri sehingga membutuhkan pola asuh dan pola didik yang berbeda. Oleh karena itu, diperlukan pemahaman yang mendalam terhadap karateristik anak, baik fisik maupun psikologis. Yang akan dibahas lebih mendalam dalam makalah ini adalah bagaimana karateristik dan pola pendekatan terhadap anak yang berada dalam usia remaja, karena masa remaja merupakan masa kritis. Bilamana anak berhasil melewati masa remaja dengan baik, dia akan menjadi orang dewasa yang baik pula, tetapi bilamana gagal melewati masa tersebut, dia akan mengalami beberapa masalah di kemudian hari.

\section{Perkembangan anak usia dini}

Anak usia dini ( 0 - 8 tahun) adalah individu yang sedang mengalami proses pertumbuhan dan perkembangan yang sangat pesat. Bahkan dikatakan sebagai lompatan perkembangan karena itulah maka usia dini dikatakan sebagai golden age (usia emas) yaitu usia yang sangat berharga dibanding usia-usia selanjutnya. Usia tersebut merupakan fase kehidupan yang unik.

\section{Karakteristik Perkembangan Anak Usia Dini}

Menurut Hurlock, Elizabeth B.,1992, karakteristik anak usia dini sebagai berikut :

a. Usia $0-1$ tahun

Pada masa bayi perkembangan fisik mengalami kecepatan luar biasa, paling cepat dibanding usia selanjutnya. Berbagai kemampuan dan ketrampilan dasar dipelajari anak pada usia ini. Beberapa karakteristik anak usia bayi dapat dijelaskan antara lain : 
1. Mempelajari ketrampilan motorik mulai dari berguling, merangkak, duduk, berdiri dan berjalan.

2. Mempelajari ketrampilan menggunakan panca indera, seperti melihat atau mengamati, meraba, mendengar, mencium dan mengecap dengan memasukkan setiap benda ke mulutnya.

3. Mempelajari komunikasi sosial. Bayi yang baru lahir telah siap melaksanakan kontrak sosial dengan lingkungannya. Komunikasi responsif dari orang dewasa akan mendorong dan memperluas respon verbal dan non verbal bayi.

Berbagai kemampuan dan ketrampilan dasar tersebut merupakan modal penting bagi anak untuk menjalani proses perkembangan selanjutnya.

b. Usia $2-3$ tahun

Anak pada usia ini memiliki beberapa kesamaan karakteristik dengan masa sebelumnya. Secara fisik anak masih mengalami pertumbuhan yang pesat. Beberapa karakteristik khusus yang dilalui anak usia $2-3$ tahun antara lain :

1. Anak sangat aktif mengeksplorasi benda-benda yang ada di sekitarnya. Ia memiliki kekuatan observasi yang tajam dan keinginan belajar yang luar biasa. Eksplorasi yang dilakukan oleh anak terhadap benda-benda apa saja yang ditemui merupakan proses belajar yang sangat efektif. Motivasi belajar anak pada usia tersebut menempati grafik tertinggi dibanding sepanjang usianya bila tidak ada hambatan dari lingkungan.

2. Anak mulai mengembangkan kemampuan berbahasa. Diawali dengan berceloteh, kemudian satu dua kata dan kalimat yang belum jelas maknanya. Anak terus belajar dan berkomunikasi, memahami pembicaraan orang lain dan belajar mengungkapkan isi hati dan pikiran.

3. Anak mulai belajar mengembangkan emosi. Perkembangan emosi anak didasarkan pada bagaimana lingkungan memperlakukan dia. Sebab emosi bukan ditemukan oleh bawaan namun lebih banyak pada lingkungan.

c. Usia $4-6$ tahun

Anak usia $4-6$ tahun memiliki karakteristik antara lain :

1. Berkaitan dengan perkembangan fisik, anak sangat aktif melakukan berbagai kegiatan. Hal ini bermanfaat untuk mengembangkan otot-otot kecil maupun besar.

2. Perkembangan bahasa juga semakin baik. Anak sudah mampu memahami pembicaraan orang lain dan mampu mengungkapkan pikirannya dalam batas-batas tertentu.

3. Perkembangan kognitif (daya pikir) sangat pesat, ditunjukkan dengan rasa ingin tahu anak yang luar biasa terhadap lingkungan sekitar. $\mathrm{Hl}$ itu terlihat dari seringnya anak menanyakan segala sesuatu yang dilihat. 
4. Bentuk permainan anak masih bersifat individu, bukan permainan sosial. Walaupun aktifitas bermain dilakukan anak secara bersama.

d. Usia $7-8$ tahun

Karakteristik perkembangan anak usia $7-8$ tahun antara lain :

1. Perkembangan kognitif anak masih berada pada masa yang cepat. Dari segi kemampuan, secara kognitif anak sudah mampu berpikir bagian per bagian. Artinya anak sudah mampu berpikir analisis dan sintesis, deduktif dan induktif.

2. Perkembangan sosial anak mulai ingin melepaskan diri dari otoritas orangtuanya. Hal ini ditunjukkan dengan kecenderungan anak untuk selalu bermain di luar rumah bergaul dengan teman sebaya.

3. Anak mulai menyukai permainan sosial. Bentuk permainan yang melibatkan banyak orang dengan saling berinteraksi.

4. Perkembangan emosi anak sudah mulai berbentuk dan tampak sebagai bagian dari kepribadian anak. Walaupun pada usia ini masih pada taraf pembentukan, namun pengalaman anak sebenarnya telah menampakkan hasil.

\section{Kondisi Yang Mempengaruhi Anak Usia Dini}

Banyak hal yang dapat mempengaruhi kondisi anak usia dini, secara garis besar dapat dikelompokkan menjadi dua yaitu :

a. Faktor bawaan

b. Faktor lingkungan

Pertama, faktor bawaan adalah faktor yang diturunkan dari kedua orangtuanya, baik yang bersifat fisik maupun psikis. Faktor bawaan lebih dominan dari pihak ayah daripada ibu atau sebaliknya. Faktor ini tidak dapat direkayasa oleh orangtua yang menurunkan. Dan hanya ditentukan oleh waktu satu detik, yaitu saat bertemunya sel sperma dan ovum. Oleh karena itu, saat ovulasi merupakan saat paling berharga untuk sepanjang hidup manusia, karena pada saat itulah diturunkan sifat bawaan yang akan terbawa sepanjang usia manusia.

Kedua, faktor lingkungan yaitu faktor yang berasal dari luar faktor bawaan, meliputi seluruh lingkungan yang dilalui oleh anak. Lingkungan dapat dipisahkan menjadi dua, yaitu lingkungan dalam kandungan dan lingkungan di luar kandungan.

Lingkungan dalam kandungan sangat penting bagi perkembangan anak. Karena perkembangan janin dalam kandungan mengalami kecepatan luar biasa, lebih cepat 200.000 kali dibanding perkembangan sesudah lahir. Oleh karena itu lingkungan yang positif dalam kandungan akan berpengaruh positif bagi perkembangan janin, demikian juga sebaliknya. 
Lingkungan di luar kandungan, juga besar pengaruhnya terhadap perkembangan anak usia dini. Sebab anak menjadi bagaimana seorang anak sangat dipengaruhi oleh bagaimana lingkungan memperlakukan dia. Lingkungan luar kandungan dibedakan menjadi tiga hal yaitu :

a. Lingkungan keluarga, yaitu lingkungan yang dialami anak dalam berinteraksi dengan anggota keluarga baik interaksi secara langsung maupun tidak langsung. Lingkungan keluarga khususnya dialami anak usia $0-3$ tahun. Usia ini menjadi landasan bagi anak untuk melalui proses selanjutnya.

b. Lingkungan masyarakat atau lingkungan teman sebaya. Seiring bertambahnya usia, anak akan mencari teman untuk berinteraksi dan bermain bersama. Kondisi teman sebaya turut menentukan bagaimana anak jadinya.

c. Lingkungan sekolah. Pada umumnya anak akan memasuki lingkungan sekolah pada usia 4 - 5 tahun atau bahkan yang 3 tahun. Lingkungan di sekolah besar pengaruhnya terhadap perkembangan anak. Sekolah yang baik akan mampu berperan secara baik dengan memberi kesempatan dan mendorong anak untuk mengaktualisasikan diri sesuai dengan kemampuan yang sesungguhnya.

\section{Pola Perkembangan Anak Usia Dini}

Perkembangan setiap anak memiliki pola yang sama, walaupun kecepatannya berbeda. Setiap anak mengikuti pola yang dapat diramalkan dengan cara dan kecepatannya sendiri. Sebagian anak berkembang dengan tertib tahap demi tahap, langkah demi langkah. Namun sebagian yang lain mengalami kecepatan melonjak. Di samping itu ada juga yang mengalami penyimpangan atau keterlambatan. Namun secara umum setiap anak berkembang dengan mengikuti pola yang sama. Beberapa pola tersebut antara lain :

a. Perkembangan Fisik

Perkembangan fisik mengikuti hukum perkembangan yang disebut "cephalocaudal" dan "proximodistal". Hukum cephalocaudal menyatakan bahwa perkembangan dimulai dari kepala kemudian menyebar ke seluruh tubuh sampai ke kaki. Sedangkan hukum proximodistal menyatakan bahwa perkembangan bergerak dari pusat sumbu ke ujung-ujungnya atau dari bagian yang dekat sumbu pusat tubuh ke bagian yang lebih jauh.

a. Perkembangan bergerak dari tanggapan umum menuju ke tanggapan khusus

Bayi pada awal perkembangan memberikan reaksi dengan menggerakkan seluruh tubuh. Semakin lama ia akan mampu memberikan reaksi dalam bentuk gerakan khusus. Demikian seterusnya dalam hal-hal lain. 
b. Perkembangan berlangsung secara berkesinambungan

Proses perkembangan diawali dari bertemunya sel sperma dan ovum yang disebut ovulasi, dan terus secara berkesinambungan hingga kematian. Kadang perlahan, kadang cepat, kadang maju terus, kadang sejenak mundur. Satu tahap perkembangan menjadi landasan bagi tahap perkembangan selanjutnya. Tidak ada pengalaman anak yang sia-sia atau hilang terhapus. Hanya tertutupi oleh pengalaman-pengalaman berikutnya.

c. Terhadap periode keseimbangan dan tidak keseimbangan

Setiap anak mengalami periode dimana ia merasa bahagia, mudah menyesuaikan diri dan lingkungannya pun bersikap positif terhadapnya. Namun juga ada masa ketidakseimbangan yang ditandai dengan kesulitan anak untuk menyesuaikan diri, sulit diatur, emosi negatif dan sebagainya. Pola tersebut bila digambarkan ibarat spiral yang bergerak melingkar dengan jangka waktu kurang lebih 6 bulan, hingga akhirnya anak menemukan ketenangan dan jati diri.

d. Terhadap tugas perkembangan yang harus dilalui anak dari waktu ke waktu

Tugas perkembangan adalah sesuatu yang harus dilakukan atau dicapai oleh anak berdasarkan tahap usianya. Tugas perkembangan bersifat khas, sesuai dengan tuntutan dan ukuran yang berlaku di masyarakat. Misalnya bayi lahir dia akan melaksanakan tugas perkembangan berguling, tengkurap, duduk, berdiri, berjalan, bermain dan seterusnya. Kualitas dan kuantitas tugas perkembangan antara satu daerah berbeda dengan daerah lain. (Sudjud, Aswarni, 1997)

\section{Peranan Ibu dalam mengenalkan Pendidikan Seks pada anak usia dini}

Pendidikan seks usia dini dapat memberikan pemahaman anak akan kondisi tubuhnya, pemahaman akan lawan jenisnya, dan pemahaman untuk menghindarkan dari kekerasan seksual. Pendidikan seks yang dimaksud di sini adalah anak mulai mengenal akan identitas diri dan keluarga, mengenal anggota-anggota tubuh mereka, serta dapat menyebutkan ciri-ciri tubuh. Cara yang dapat digunakan mengenalkan tubuh dan ciri-ciri tubuh antara lain melalui media gambar atau poster, lagu dan permainan. Pemahaman pendidikan seks di usia dini ini diharapkan anak agar anak dapat memperoleh informasi yang tepat mengenai seks. Hal ini dikarenakan adanya media lain yang dapat mengajari anak mengenai pendidikan seks ini, yaitu media informasi. Sehingga anak dapat memperoleh informasi yang tidak tepat dari media massa terutama tayangan televisi yang kurang mendidik.

Dengan mengajarkan pendidikan seks pada anak, diharapkan dapat menghindarkan anak dari risiko negatif perilaku seksual maupun perilaku menyimpang. Dengan sendirinya anak diharapkan akan tahu mengenai seksualitas dan akibat-akibatnya bila dilakukan tanpa mematuhi 
aturan hukum, agama, dan adat istiadat, serta dampak penyakit yang bisa ditimbulkan dari penyimpangan tersebut.

Untuk membahas masalah seks pada anak memang tidak mudah, apalagi yang ada di dalam pikiran orang tua ketika mendengar kalimat "pendidikan seks di usia dini” adalah mengajarkan anak untuk berhubungan seksual. Sehingga orang tua tidak ingin atau enggan untuk mengajarkannya. Namun, mengajarkan pendidikan seks pada anak harus diberikan agar anak tidak salah melangkah dalam hidupnya.

Menurut Dr Rose Mini AP, M Psi seorang psikolog pendidikan, seks bagi anak wajib diberikan orangtua sedini mungkin. "Pendidikan seks wajib diberikan orangtua pada anaknya sedini mungkin. Tepatnya dimulai saat anak masuk play group (usia 3-4 tahun), karena pada usia ini anak sudah dapat mengerti mengenai organ tubuh mereka dan dapat pula dilanjutkan dengan pengenalan organ tubuh internal.(http://edupsi.wordpress.com/2010/04/03/mengajarkanpendidikan-seks-pada-anak)

Tidak ada cara instan untuk mengajarkan seks pada anak kecuali melakukannya setahap demi setahap sejak dini. Kita dapat mengajarkan anak mulai dari hal yang sederhana, dan menjadikannya sebagai satu kebiasaan sehari-hari. Tanamkan pengertian pada anak layaknya kita menanamkan pengertian tentang agama. Kita tahu tidak mungkin mengajarkan agama hanya dalam tempo satu hari saja dan lantas berharap anak akan mampu menjalankan ibadahannya, maka demikian juga untuk seks.

Pengenalan seks pada anak dapat dimulai dari pengenalan mengenai anatomi tubuh. Kemudian meningkat pada pendidikan mengenai cara berkembangbiak makhluk hidup, yakni pada manusia dan binatang. Nah, kalau sudah tahu, orangtua dapat memberi tahu apa saja dampak-dampak yang akan diterima bila anak begini atau begitu,"Salah satu cara menyampaikan pendidikan seksual pada anak dapat dimulai dengan mengajari mereka membersihkan alat kelaminnya sendiri. Dengan cara "Mengajari anak untuk membersihkan alat genitalnya dengan benar setelah buang air kecil (BAK) maupun buang air besar (BAB), agar anak dapat mandiri dan tidak bergantung dengan orang lain. Pendidikan ini pun secara tidak langsung dapat mengajarkan anak untuk tidak sembarangan mengizinkan orang lain membersihkan alat kelaminnya.

Pengenalan seks pada anak dapat dimulai dari pengenalan mengenai anatomi tubuh. Kemudian meningkat pada pendidikan mengenai cara berkembangbiak makhluk hidup, misalnya pada manusia. Sehingga orangtua dapat memberikan penjelasan mengenai dampak-dampak yang akan diterima bila anak sudah melakukan hal-hal yang menyimpangnya.

Cara menyampaikan pendidikan seksual itu pun tidak boleh terlalu vulgar, karena justru akan berdampak negatif pada anak. Di sini orangtua sebaiknya melihat faktor usia. Artinya ketika akan mengajarkan anak mengenai pendidikan seks, lihat sasaran yang dituju. Karena ketika anak sudah diajarkan mengenai seks, anak akan kristis dan ingin tahu tentang segala hal. 
Berikut adalah cara yang dapat dilakukan oleh orang tua untuk menyampaikan informasi mengenai pendidikan seks pada anak.

Bersikap jujur dan terbuka; Kita harus menyampaikan informasi yang benar dan apa adanya. Tidak boleh menjawab pertanyaan anak dengan asal-asalan, tidak akurat apalagi sampai melenceng dari subjek pertanyaan. Jangan takut memberikan informasi yang jujur karena ini akan mengajari anak untuk mau juga bersikap jujur dan terbuka kepada orang tuanya.

Dengan jujur, kita tidak menyesatkan anak dengan informasi yang tidak benar, karena bisa melahirkan rasa tidak percaya anak pada orang tuanya. Faktanya banyak orang tua yang tidak besikap jujur ketika memberikan informasi seks pada anak, seperti menyebutkan organ seksual dengan istilah-istilah yang lain.

Santai;Belajarlah bersikap santai, wajar, dan biasa-biasa saja.Jangan membesar-besarkan masalah, karena menganggap seks merupakan topik yang berat. Usahakan untuk rileks dengan menjaga intonasi suara ketika menjawab pertanyaan anak.

Tidak boleh bersikap heboh dan berlebih-lebihan. Kualitas kata atau kalimat sangat bergantung kepada cara pengucapannya. Kata yang sama namun di ucapkapkan dengan intonasi yang berbeda akan memberikan dampak yang juga berbeda pada si penerima pesan. Dalam hal seks, kita harus belajar untuk menghilangkan rasa risih dan takut ketika menjelaskannya pada anak.

Jangan biarkan anak terkontaminasi pesan non verbal yang keliru hanya karena orang tua tidak mampu mengikis keresahannya setiap kali membiacarakan seks. Sangat disarankan agar selaku orang tua kita lebih dulu melepaskan diri dari semua persepsi seks dewasa yang erotis dan mesum ketika menginformasikannya pada anak agar anak tidak menangkap pesan yang keliru. Hindari kemarahan yang negatif; Kemarahan negatif berarti marah dan menolak pertanyaan anak melalui hardikan dan umpatan kata-kata kasar. Ini sangat berpengaruh buruk pada anak. Hindari juga kebiasaan mengatakan pada anak bahwa seks itu dosa, kotor, dan tak pantas untuk dibicarakan. Semua sikap negatif semacam ini akan menanamkan persepsi negatif tentang seks pada anak yang pada akhirnya akan memicu timbulnya pemahaman keliru tentang seks. Tentu anda tidak ingin anak Anda tumbuh dengan persepsi yang negatif tentang seks. Mari ajarkan mereka mengenai pendidikan seks yang dimulai sejak usia dini.

Ada beberapa tips dalam memberikan pemahaman anak tentang seks antara lain: Menanamkan rasa malu, misalnya dengan membiasakan anak untuk ganti baju di tempat tertutup; Menanamkan jiwa maskulinitas pada anak laki-laki dan jiwa feminitas pada anak perempuan, misalnya dengan berpakaian sesuai dengan jenis kelaminnya; Memisahkan tempat tidur mereka, terutama dengan saudara yang berjenis kelamin berbeda; Mengenalkan waktu berkunjung (meminta izin dalam 3 waktu), untuk menanamkan dan menghormati privasi masingmasing saat berada di dalam kamar; Mendidik anak untuk menjaga pandangan matanya dari halhal yang mengandung unsur pornografi; Mengajari anak untuk menjaga kebersihan alat kelamin sekaligus juga mengajari anak tentang najis, membiasakan anak buang air kecil pada tempatnya 
(toilet), dengan begitu anak akan terbiasa mandiri dan tidak bergantung pada orang lain. Selain itu, secara tidak langsung mengajari anak untuk tidak sembarangan mengizinkan orang lain membersihkan alat kelaminnya.

Pendidikan seks untuk anak-anak walaupun diberikan sejak dini juga harus memperhatikan faktor usia dan tingkat pemahaman anak. Beri penjelasan dengan bahasa yang dimengerti oleh anak. Pendidikan dapat diawali dengan mengenalkan identitas anak, mengenalkan perbedaan ciri-ciri tubuh anak perempuan dan laki-laki. Selanjutnya jelaskan pada anak tentang bagian tubuh yang tersembunyi, yang dianggap tabu untuk disebutkan namanya. Menjelaskan pada anak apa adanya bukan berarti jorok. Memang tidak gampang memberikan penjelasan tersebut. Yang penting sesuai. Yang tidak kalah penting adalah menciptakan hubungan yang baik dengan anak, dengan begitu anak akan mudah menerima masukan dari orangtua, dan yang tidak ketinggalan adalah membina hubungan kerjasama dengan pihak sekolah, dengan tujuan pergaulan anak di sekolah dapat terpantau, dan tidak ada salahnya pendidikan seks untuk anak juga diadakan di sekolah.

Dengan demikian anak sudah mempunyai bekal untuk kehidupannya kelak ketika menginjak masa remaja dengan menjaga dirinya sebaik mungkin. Selain itu anak menjadi tahu batasan dan sebab akibat dari bahaya pergaulan bebas. Beberapa tahapan umur dan cara memberikan pendidikan seks sesuai dengan tingkat usia anak anda.

\section{A. Balita (1-5 tahun)}

Pada usia ini, Anda bisa mulai menanamkan pendidikan seks. Caranya cukup mudah, yaitu dengan mulai memperkenalkan kepada si kecil organ-organ seks miliknya secara singkat. Tidak perlu memberi penjelasan detail karena rentang waktu atensi anak biasanya pendek. Misalnya saat memandikan si kecil, Anda bisa memberitahu berbagai organ tubuh anak, seperti rambut, kepala, tangan, kaki, perut, dan jangan lupa penis dan vagina atau vulva. Lalu terangkan perbedaan alat kelamin dari lawan jenisnya, misalnya jika si kecil memiliki adik yang berlawanan jenis. Selain itu, tandaskan juga bahwa alat kelamin tersebut tidak boleh dipertontonkan dengan sembarangan, dan terangkan juga jika ada yang menyentuhnya tanpa diketahui orang tua, maka si kecil harus berteriak keras-keras dan melapor kepada orang tuanya. Dengan demikian, anak-anak Anda bisa dilindungi terhadap maraknya kasus kekerasan seksual dan pelecehan seksual terhadap anak.

\section{B. Usia 3 - 10 tahun}

Pada usia ini, anak biasanya mulai aktif bertanya tentang seks. Misalnya anak akan bertanya dari mana ia berasal. Atau pertanyaan yang umum seperti bagaimana asal-usul bayi. Jawaban-jawaban yang sederhana dan terus terang biasanya efektif. Contoh \#1: "Bayi berasal dari mana?" Anda bisa menjawab dari perut ibu. Atau Anda bisa tunjukkan seorang ibu yang sedang hamil dan menunjukkan lokasi bayi di perut ibu tersebut. Contoh \#2: "Bagaimana bayi keluar dari perut Ibu?" Anda bisa menjawab bayi keluar dari lubang vagina atau vulva supaya bisa keluar dari perut ibu. Contoh \#3: "Mengapa bayi bisa ada di perut?" Anda bisa menjawab 
bahwa bayi di perut ibu karena ada benih yang diberikan oleh ayah kepada ibu. Caranya adalah ayah memasukkan benih tersebut menggunakan penis dan melalui vagina dari ibu. Itu yang dinamakan hubungan seks, dan itu hanya boleh dilakukan oleh pria dan wanita yang telah menikah.

\section{Usia Menjelang Remaja}

Saat anak semakin berkembang, mulai saatnya Anda menerangkan mengenai haid, mimpi basah, dan juga perubahan-perubahan fisik yang terjadi pada seorang remaja. Anda bisa terangkan bahwa si gadis kecil akan mengalami perubahan bentuk payudara, atau terangkan akan adanya tumbuh bulu-bulu di sekitar alat kelaminnya.

Usia Remaja

Pada saat ini, seorang remaja akan mengalami banyak perubahan secara seksual. Anda perlu lebih intensif menanamkan nilai moral yang baik kepadanya. Berikan penjelasan mengenai kerugian seks bebas seperti penyakit yang ditularkan dan akibat-akibat secara emosi.

Diharapkan, pendidikan seks sejak dini akan menghindari kehamilan di luar pernikahan saat anak-anak bertumbuh menjadi remaja dan saat dewasa kelak. Tidak perlu tabu membicarakan seks dalam keluarga. Karena anak Anda perlu mendapatkan informasi yang tepat dari orang tuanya, bukan dari orang lain tentang seks.

Karena rasa ingin tahu yang besar, jika anak tidak dibekali pendidikan seks, maka anak tersebut akan mencari jawaban dari orang lain, dan akan lebih menakutkan jika informasi seks didapatkan dari teman sebaya atau Internet yang informasinya bisa jadi salah. Karena itu, lindungi anak-anak Anda sejak dini dengan membekali mereka pendidikan mengenai seks dengan cara yang tepat.

Menurut Zulia Ilmawati, psikolog, pemerhati masalah anak dan remaja di antara pokokpokok pendidikan seks yang bersifat praktis, yang perlu diterapkan dan diajarkan kepada anak adalah sebagai berikut:

1. Menanamkan rasa malu pada anak. Rasa malu harus ditanamkan kepada anak sejak dini. Jangan biasakan anak-anak, walau masih kecil, bertelanjang di depan orang lain; misalnya ketika keluar kamar mandi, berganti pakaian, dan sebagainya. Membiasakan anak perempuan sejak kecil berbusana Muslimah menutup aurat juga penting untuk menanamkan rasa malu sekaligus mengajari anak tentang auratnya.

2. Menanamkan jiwa maskulinitas pada anak laki-laki dan jiwa feminitas pada anak perempuan. Secara fisik maupun psikis, laki-laki dan perempuan mempunyai perbedaan mendasar. Perbedaan tersebut telah diciptakan sedemikian rupa oleh Allah. Adanya perbedaan ini bukan untuk saling merendahkan, namun semata-mata karena fungsi yang berbeda yang kelak akan diperankannya. Mengingat perbedaan tersebut, Islam telah memberikan tuntunan agar masingmasing fitrah yang telah ada tetap terjaga. Islam menghendaki agar laki-laki memiliki 
kepribadian maskulin, dan perempuan memiliki kepribadian feminin. Islam tidak menghendaki wanita menyerupai laki-laki, begitu juga sebaliknya. Untuk itu, harus dibiasakan dari kecil anakanak berpakaian sesuai dengan jenis kelaminnya. Mereka juga harus diperlakukan sesuai dengan jenis kelaminnya. Ibnu Abbas ra. berkata: Rasulullah saw. melaknat laki-laki yang berlagak wanita dan wanita yang berlagak meniru laki-laki. (HR al-Bukhari).

\section{Memisahkan tempat tidur mereka.}

Usia antara 7-10 tahun merupakan usia saat anak mengalami perkembangan yang pesat. Anak mulai melakukan eksplorasi ke dunia luar. Anak tidak hanya berpikir tentang dirinya, tetapi juga mengenai sesuatu yang ada di luar dirinya. Pemisahan tempat tidur merupakan upaya untuk menanamkan kesadaran pada anak tentang eksistensi dirinya. Jika pemisahan tempat tidur tersebut terjadi antara dirinya dan orangtuanya, setidaknya anak telah dilatih untuk berani mandiri. Anak juga dicoba untuk belajar melepaskan perilaku lekatnya (attachment behavior) dengan orangtuanya. Jika pemisahan tempat tidur dilakukan terhadap anak dengan saudaranya yang berbeda jenis kelamin, secara langsung ia telah ditumbuhkan kesadarannya tentang eksistensi perbedaan jenis kelamin.

4. Mengenalkan waktu berkunjung (meminta izin dalam 3 waktu). Tiga ketentuan waktu yang tidak diperbolehkan anak-anak untuk memasuki ruangan (kamar) orang dewasa kecuali meminta izin terlebih dulu adalah: sebelum shalat subuh, tengah hari, dan setelah shalat isya. Aturan ini ditetapkan mengingat di antara ketiga waktu tersebut merupakan waktu aurat, yakni waktu ketika badan atau aurat orang dewasa banyak terbuka (Lihat: QS al-Ahzab [33]: 13). Jika pendidikan semacam ini ditanamkan pada anak maka ia akan menjadi anak yang memiliki rasa sopan-santun dan etika yang luhur. 5. Mendidik menjaga kebersihan alat kelamin. Mengajari anak untuk menjaga kebersihan alat kelamin selain agar bersih dan sehat sekaligus juga mengajari anak tentang najis. Anak juga harus dibiasakan untuk buang air pada tempatnya (toilet training). Dengan cara ini akan terbentuk pada diri anak sikap hati-hati, mandiri, mencintai kebersihan, mampu menguasai diri, disiplin, dan sikap moral yang memperhatikan tentang etika sopan santun dalam melakukan hajat.

6. Mengenalkan mahram-nya. Tidak semua perempuan berhak dinikahi oleh seorang laki-laki. Siapa saja perempuan yang diharamkan dan yang dihalalkan telah ditentukan oleh syariat Islam. Ketentuan ini harus diberikan pada anak agar ditaati. Dengan memahami kedudukan perempuan yang menjadi mahram, diupayakan agar anak mampu menjaga pergaulan sehari-harinya dengan selain wanita yang bukan mahram-nya. Inilah salah satu bagian terpenting dikenalkannya kedudukan orang-orang yang haram dinikahi dalam pendidikan seks anak. Dengan demikian dapat diketahui dengan tegas bahwa Islam mengharamkan incest, yaitu pernikahan yang 
dilakukan antar saudara kandung atau mahram-nya. Siapa saja mahram tersebut, Allah Swt telah menjelaskannya dalam surat an-Nisa' (4) ayat 22-23.

7. Mendidik anak agar selalu menjaga pandangan mata. Telah menjadi fitrah bagi setiap manusia untuk tertarik dengan lawan jenisnya. Namun, jika fitrah tersebut dibiarkan bebas lepas tanpa kendali, justru hanya akan merusak kehidupan manusia itu sendiri. Begitu pula dengan mata yang dibiarkan melihat gambar-gambar atau film yang mengandung unsur pornografi. Karena itu, jauhkan anak-anak dari gambar, film, atau bacaan yang mengandung unsur pornografi dan pornoaksi.

8. Mendidik anak agar tidak melakukan ikhtilât. Ikhtilât adalah bercampur-baurnya laki-laki dan perempuan bukan mahram tanpa adanya keperluan yang diboleh-kan oleh syariat Islam. Perbuatan semacam ini pada masa sekarang sudah dinggap biasa. Mereka bebas mengumbar pandangan, saling berdekatan dan bersentuhan; seolah tidak ada lagi batas yang ditentukan syariah guna mengatur interaksi di antara mereka. Ikhtilât dilarang karena interaksi semacam ini bisa menjadi mengantarkan pada perbuatan zina yang diharamkan Islam. Karena itu, jangan biasakan anak diajak ke tempat-tempat yang di dalamnya terjadi percampuran laki-laki dan perempuan secara bebas.

9. Mendidik anak agar tidak melakukan khalwat. Dinamakan khalwat jika seorang laki-laki dan wanita bukan mahram-nya berada di suatu tempat, hanya berdua saja. Biasanya mereka memilih tempat yang tersembunyi, yang tidak bisa dilihat oleh orang lain. Sebagaimana ikhtilât, khalwat pun merupakan perantara bagi terjadinya perbuatan zina. Anak-anak sejak kecil harus diajari untuk menghindari perbuatan semacam ini. jika bermain, bermainlah dengan sesama jenis. Jika dengan yang berlainan jenis, harus diingatkan untuk tidak ber-khalwat.

10. Mendidik etika berhias. Berhias, jika tidak diatur secara islami, akan menjerumuskan seseorang pada perbuatan dosa. Berhias berarti usaha untuk memperindah atau mempercantik diri agar bisa berpenampilan menawan. Tujuan pendidikan seks dalam kaitannya dengan etika berhias adalah agar berhias tidak untuk perbuatan maksiat.

11. Ihtilâm dan haid. Ihtilâm adalah tanda anak laki-laki sudah mulai memasuki usia balig. Adapun haid dialami oleh anak perempuan. Mengenalkan anak tentang ihtilâm dan haid tidak hanya sekadar untuk bisa memahami anak dari pendekatan fisiologis dan psikologis semata. Jika terjadi ihtilâm dan haid, Islam telah mengatur beberapa ketentuan yang berkaitan dengan masalah tersebut, antara lain kewajiban untuk melakukan mandi. Yang paling penting, harus ditekankan bahwa kini mereka telah menjadi Muslim dan Muslimah dewasa yang wajib terikat pada semua ketentuan syariah. Artinya, mereka harus diarahkan menjadi manusia yang bertanggung jawab atas hidupnya sebagai hamba Allah yang taat. 


\section{Kesimpulan}

Pemahaman pendidikan seks di usia dini ini diharapkan anak agar anak dapat memperoleh informasi yang tepat mengenai seks. Hal ini dikarenakan adanya media lain yang dapat mengajari anak mengenai pendidikan seks ini, yaitu media informasi. Sehingga anak dapat memperoleh informasi yang tidak tepat dari media massa terutama tayangan televisi yang kurang mendidik. Dengan mengajarkan pendidikan seks pada anak, diharapkan dapat menghindarkan anak dari risiko negatif perilaku seksual maupun perilaku menyimpang. Dengan sendirinya anak diharapkan akan tahu mengenai seksualitas dan akibat-akibatnya bila dilakukan tanpa mematuhi aturan hukum, agama, dan adat istiadat, serta dampak penyakit yang bisa ditimbulkan dari penyimpangan tersebut.

Tingginya kasus kekerasan seksual pada anak (child abuse) yang dilakukan oleh orangorang terdekat anak termasuk keluarga menunjukkan pentingnya pemahaman akan pendidikan seks usia dini. Masalah pendidikan seks kurang diperhatikan orang tua pada masa kini sehingga mereka menyerahkan semua pendidikan termasuk pendidikan seks pada sekolah.. Padahal yang bertanggungjawab mengajarkan pendidikan seks di usia dini adalah orang tua, sedangkan sekolah hanya sebagai pelengkap dalam memberikan informasi kepada si anak. Peranan orang tua, terutama ibu sangat strategis dalam mengenalkan pendidikan seks sejak dini kepada anakanak mereka.

\section{DAFTAR PUSTAKA}

http://edupsi.wordpress.com/2010/04/03/mengajarkan-pendidikan-seks-pada-anak, Diakses 15 September 2010

http://dhyanthea.blogspot.com/2006/05/pendidikan-seks-untuk-anak.html

http://www.voa-islam.com/muslimah/pendidikan/2010/07/18/8307/pendidikan-seks-untuk-anakanak/, Diakases 10 oktober 2010

Hurlock, Elizabeth B.,1992. Perkembangan Anak, Jilid I dan Ikan Mas, Jakarta : Erlangga,

Risman, Elly, Makalah Seminar.2006 "Sex Education for The Children” Pendidikan Seksualitas Pada_Pada Anak Sejak Usia Dini

Zulia Ilmawati, 2010. Onesaiful.blogspot.com. Diakses 2 September 2010

Sudjud, Aswarni, 1997. Konsep Pendidikan Pra Sekolah, FIP IKIP Yogyakarta, 